\title{
Er regnemodellerne for rationelle?
}

Temanummer: Finansministeriet som vagt- og overhund

Artiklen diskuterer fordele og ulemper ved at inddrage adfærdsøkonomiske effekter i de regnemodeller, som benyttes af bl.a. Finansministeriet. Artiklen bruger den seneste reform af dagpengesystemet fra 2015 som case. Artiklen konkluderer, at selvom der er vanskeligheder ved at fastlægge den præcise størrelsesorden af potentielle adfærdsøkonomiske effekter, bør de medregnes i fremtidens regnemodeller. De usikkerheder, der knytter sig til størrelsen af de adfærdsøkonomiske effekter, bør ligesom usikkerhederne på mange andre økonomiske parametre håndteres ved følsomhedsberegninger, der giver et reelt billede af usikkerheden på skønnene.

\section{Indledning}

Debatten om de økonomiske modeller, som benyttes af bl.a. Finansministeriet i forbindelse med politikudvikling, har især drejet sig om de dynamiske effekter af offentlige udgifter og indtægter. De dynamiske effekter er afledte effekter af økonomiske tiltag, f.eks. adfærdsmæssige ændringer som følge af ændrede satser i dagpengesystem eller skattesystem. Ændringer i den økonomiske politik eller konsekvenser af nye reformer kan imidlertid også have helt andre adfærdsmæssige effekter, som ikke nødvendigvis direkte kan knyttes til egentlige økonomiske incitamenter o.l., men derimod hænger sammen med, hvordan nye regler eller politikker implementeres i praksis. Disse effekter betegnes ofte adfærdsøkonomiske effekter eller mere populært "nudging-effekter".

I denne artikel diskuteres betydningen af adfærdsøkonomiske effekter med udgangspunkt i erfaringerne fra Dagpengekommissionens arbejde i 2014-15. Dagpengekommissionen blev nedsat i sommeren 2014 og havde i opdrag at komme med forslag til en reform af dagpengesystemet, der kunne løse det på tidspunktet betydelige politiske problem, nemlig at forholdsvis mange personer faldt ud af dagpengesystemet. Dette var især en konsekvens af de tidligere års dagpengereformer, som havde reduceret dagpengeperioden fra fire til to år kombineret med svage konjunkturer i årene omkring 2014.

Kommissionens tidlige analyser viste, at tre ud af fire, der i årene før 2014 opbrugte deres ret til dagpenge, havde under fire måneders beskæftigelse. En ud af fire havde ingen beskæftigelse. De "udfaldne" ledige var derfor meget langt fra overhovedet at genoptjene ret til dagpenge, idet kravet til genoptjening var 1924 timers beskæftigelse (svarende til et års beskæftigelse) inden for de

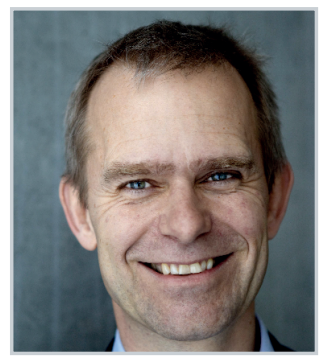

JON KVIST

Professor, ph.d. Institut for Samfundsvidenskab og erhverv,

RUC

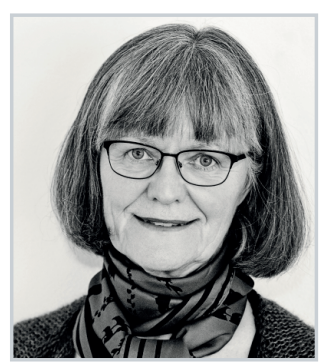

NINA SMITH

Professor,

Institut for Økonomi,

Aarhus Universitet 
sidste tre år. Kommissionens analyser ledte hurtigt frem til, at en af hovedudfordringerne ved det eksisterende system var, at det var ufleksibelt og reelt krævede, at de ledige havde en meget rationel og fremadskuende adfærd, hvor de kunne gennemskue de langsigtede økonomiske konsekvenser af deres adfærd. Virkeligheden tydede på, at mange ledige ikke besad denne rationalitet og forudseenhed.

Derfor var en hovedudfordring at designe et system, der ville give flere ledige en bedre kontakt til arbejdsmarkedet og undgå lange ledighedsperioder uden nogen form for genoptjening af de nødvendige 1924 timers beskæftigelse. Den mere traditionelle tilgang til at ændre denne adfærd kunne være at sænke dagpengene meget tidligt i ledighedsperioden. Men Dagpengekommissionens analyser og diskussioner ledte frem til, at der også kunne være andre veje end de rent økonomiske incitamenter, som grundlæggende forudsætter, at de ledige agerer som helt rationelle agenter. Derfor vendte vi os mod samfundsvidenskabelige discipliner, som kunne informere os om denne problematik. Adfærdsøkonomi og nudging var to sådanne bud.

I denne artikel ser vi nærmere på, hvad adfærdsøkonomisk teori omhandler, og hvordan adfærdsøkonomi kan bruges i praksis med udgangspunkt i Dagpengekommissionens arbejde i 2014-15. På baggrund af erfaringerne fra Dagpengekommissionen diskuterer vi slutteligt, hvorvidt adfærdsøkonomi kan informere Finansministeriets regnemodeller.

\section{Hvad er adfærdsøkonomi?}

Behavioral economics, eller adfærdsøkonomi, handler om individers ageren i økonomiske spørgsmål. Især er man optaget af at forklare beslutningsadfærd, som ikke umiddelbart kan forklares ved traditionel eller klassisk neoklassisk teori, ved at bruge psykologiske indsigter. Det vil sige, man udvider den traditionelle neoklassiske model til at omfatte andre antagelser om individers beslutninger og ageren.

I dag er adfærdsøkonomi en accepteret og integreret del af mainstream mikro-økonomi. Det kan illustreres ved arbejdet bag tre nobelpriser i økonomi.

Den første nobelpris gik således i 1978 til økonom, statskundskabsforsker og kognitive psykolog Herbert Simon, fordi han var blandt de første, der problematiserede antagelsen om rational beslutningstagen. Blandt andet på grund af begrænset tænkekapacitet, informationer og tid agerer vi, ifølge Simon (1982), også begrænset rationelt (for en gennemgang af jobsøgning med begrænset rationalitet, se Frid-Nielsen, 2017).

Adfærdsøkonomi studerer empirisk, hvorvidt og hvordan individer afviger fra neoklassisk økonomi og finder, at afvigelserne er irrationelle og systematisk forudsigelige (Ariely, 2008).

Nogle af afvigelserne fra konventionelle antagelser i neoklassisk økonomisk er: 
- Modificeret eller begrænset optimering: Man bruger tommelfingerregler, hvis beslutninger er komplekse og tidskrævende.

- Hyperbolske eller tidsinkonsistente præferencer: Man udviser kortsigtet, irrationel adfærd.

- Begrænset selvkontrol: Man er i praksis ude af stand til at gennemføre rationel optimering.

- Asymmetri med hensyn til gevinster og tab: Man har tabsaversion.

- Stereotyper og kontekst: Faktorer uden reel betydning for en beslutning påvirker alligevel beslutningstagen.

Den anden nobelpris i økonomi gik i 2002 til psykologen Daniel S. Kahneman, fordi han sammen med kollegaen Amos Tversky (1937-1996) har stået for at introducere system $1 \mathrm{og}$ system 2 . Det første system bruger vi til at træffe hurtige beslutninger ofte ud fra mavefornemmelser og tommelfingerregler. Det andet system bruger vi, når vi mere langsomt bearbejder relevante data baseret på accepterede regler. Kahnemans pointe er, at vi ofte bruger system 1, det hurtige, irrationelle system, selv når vi har at gøre med økonomiske spørgsmål (Kahneman, 2011). System 1 bidrager således til at forklare afvigelserne fra de konventionelle antagelser.

\section{Nudging}

Den tredje nobelpris i økonomi gik i 2017 til økonomen Richard M. Thaler for hans bidrag netop til adfærdsøkonomi. Thaler blev sammen med kollega Cass R. Sunstein i 2008 kendt for deres bog om nudging (Thaler og Sunstein, 2008). De pointerer, at individer har særligt svært ved at træffe beslutninger, når valg-situationen er karakteriseret ved:

- Forsinkede effekter, især ved fordele nu og omkostninger senere

- Ved sjældne beslutninger

- Dårlig feedback

- Uklar sammenhæng mellem valg og dets konsekvenser

I sådanne situationer tenderer man til at holde fast i den nuværende situation (kendt som status quo-bias), især igennem at blive ved standardvalget, at udskyde handling (udskydelsesbias), eller man lader sig påvirke af, hvad andre har valgt eller sagt (forankring og sociale normer). For en gennemgang af adfærdsøkonomi i forhold til beskæftigelsespolitik og arbejdsløshedsforsikring, se Babcock et al. (2012), Dohmen (2014) og Kvist (2015).

Nudge-litteraturen lægger stor vægt på god valg-arkitektur. Med dette menes, at man:

- indbygger incitamenter

- laver forståelige fremstillinger af konsekvenser af valg, der forbedrer folks evne til at kortlægge og vælge løsninger

- giver feedback på valg

- strukturerer og designer komplekse valgsituationer 


\section{Finansministeriets regnemodeller og adfærdsøkonomiske effekter i dagpengesystemet}

De traditionelle danske regnemodeller, som har været benyttet af bl.a. Finansministeriet, har ikke inddraget adfærdsøkonomiske effekter. I regnemodellerne indregnes mange forskellige slags adfærds-elasticiteter, som måler sammenhænge mellem økonomiske parametre og adfærd. I forhold til dagpengessystemet arbejdes der i "Dagpengemodellen" med forventningseffekten og ydelseseffekten af dagpengereglerne, se Dagpengekommissionen (2015a).

Hvis de lediges adfærd er præget af begrænset rationalitet, tommelfingerregler m.v., som ikke direkte modelleres i de estimerede sammenhænge, der ligger bag de anvendte elasticiteter, kan dette rent principielt give to problemer. For det første vil de estimerede elasticiteter ikke nødvendigvis være korrekte, hvis der sker større reformer af en ordning, fordi udformningen af ordningen også kan have adfærdsøkonomiske konsekvenser, som der ikke er kontrolleret for i de empiriske undersøgelser, der ligger bag de estimerede elasticiteter.

Det andet - og måske langt mere interessante problem - er, at man ved at ignorere adfærdsøkonomiske effekter spiller sig nogle vigtige policy-muligheder af hænde. Hvis adfærdsøkonomiske effekter er med til at påvirke adfærden hos de ledige, kan en mere hensigtsmæssig indretning af dagpengesystemet ("nudging"-elementer) i teorien tænkes at få de ledige til at udvise en adfærd, der er mere rationel for dem selv og for samfundet. Nudging-indretning af dagpengesystemet kan i så fald aflaste brugen af økonomiske incitamenter. Eller mere direkte udtrykt: Hvis dagpengesystemets indretning nudger de ledige til en mere rationel adfærd, er der mindre behov for skrappe økonomiske incitamenter til at komme i arbejde.

\section{Dagpengekommissionens overvejelser}

Samtidig med Dagpengekommissionens arbejde var der alternative reformforslag til at reducere problemet med udfald fra dagpengesystemet, både i det interne arbejde i Dagpengekommissionen og forslag fra bl.a. Det økonomiske Råd (2014). Disse forslag byggede på at nedsætte kompensationsgraden, forlænge dagpengeperioden eller at indføre en såkaldt trappemodel med en højere dagpengesats i den første del af ydelsesperioden, som derefter i trin ville blive udbetalt på lavere niveauer.

I stedet foreslog Dagpengekommissionen (2015b), at man skulle forsøge sig med små innovative justeringer inspireret af adfærdsøkonomi og nudging mv. Det var kommissionens vurdering, at de samme positive effekter og tilskyndelser til at finde beskæftigelse kunne opnås ved andre midler end ved at justere selve kompensationsgraden nedad. Selvom der i kommissionen var en forventning om disse positive adfærdsøkonomiske effekter, havde det dog ingen indflydelse på, hvordan Dagpengemodellen beregnede provenuvirkningerne af forslaget. 
Dagpengekommissionens analyser pegede på, at det daværende system var yderst komplekst, og at det derfor var heroisk at antage, at individer kunne overskue systemet, og at dem, der kunne, ofte blev mødt med uhensigtsmæssige eller uklare incitamentsstrukturer forårsaget af forskellige hensyns interageren. Fx ville man få genberegnet en lavere ydelse, hvis man tog et job, der var lavere lønnet end det første job forud for ledigheden. Fx afhang ydelsesperiodens forlængelse af, om den ledige nåede et års beskæftigelse, blot en dag mindre betød ingen forlængelse. Fx betød principper om optjening på dagsniveau og forbrug på ugeniveau, at man ved en dags arbejde mistede en uges dagpenge men kun optjente en dags beskæftigelse (Dagpengekommissionen, 2015b).

Hvis det er svært at identificere de økonomiske incitamenter, eller hvis kompleksiteten er stor, kan det være svært at forstå konsekvenserne af valg. I sådanne situationer vil den adfærdsøkonomiske teori tilsige, at status quo- og udskyder-bias ofte bliver vinderne. I det konkrete tilfælde med dagpengesystemet kan det betyde, at den ledige vil takke nej til eventuelle tilbud om job af kortere varighed eller med en dårlig aflønning, og at den ledige vil udskyde ansøgning, til CV er pudset af, som i øvrigt er udskudt til morgendagen.

\section{Beskæftigelseskonto med klare principper}

Et vigtigt element i Dagpengekommissionens forslag blev den ny fleksible genoptjening med 1:2-princippet. Kort sagt var målet med 1:2-princippet at sikre, at den ledige vidste, at det altid kan betale sig at tage et arbejde, uafhængig af jobbets længde, aflønning, placering i forhold til ledighedsperioden mv. Med andre ord, hvis man arbejder en time, betyder det en forlængelse af ydelsesperioden med to timer, dvs. der bliver sat to timer ind på beskæftigelseskontoen. Det enkle 1:2-princip krævede bl.a., at man fjernede genberegning af dagpengeydelsens størrelse, og at man overgik til optjening og forbrug af dagpenge på timeniveau. Selv i situationer, hvor man ikke opnår et års beskæftigelse, som krævet i det gamle system, forbedres den sociale tryghed målt ved længden af dagpengeperioden.

Inspireret af principperne for god valg-arkitektur foreslog Dagpengekommissionen, at man indførte en Beskæftigelseskonto med Dagpengetællere på den lediges joblog på jobnet.dk. Dagpengetælleren til venstre i Figur 1 informerer den ledige om 1:2-princippet, og hvor lang en forlængelse den ledige har optjent gennem beskæftigelse. Dagpengetælleren til højre viser gennem et timeglas forbruget af dagpenge og angiver dato for udløb af dagpengeperioden. 
Figur 1. Dagpengetællerne på den lediges joblog viser optjening og forbrug af dagpenge

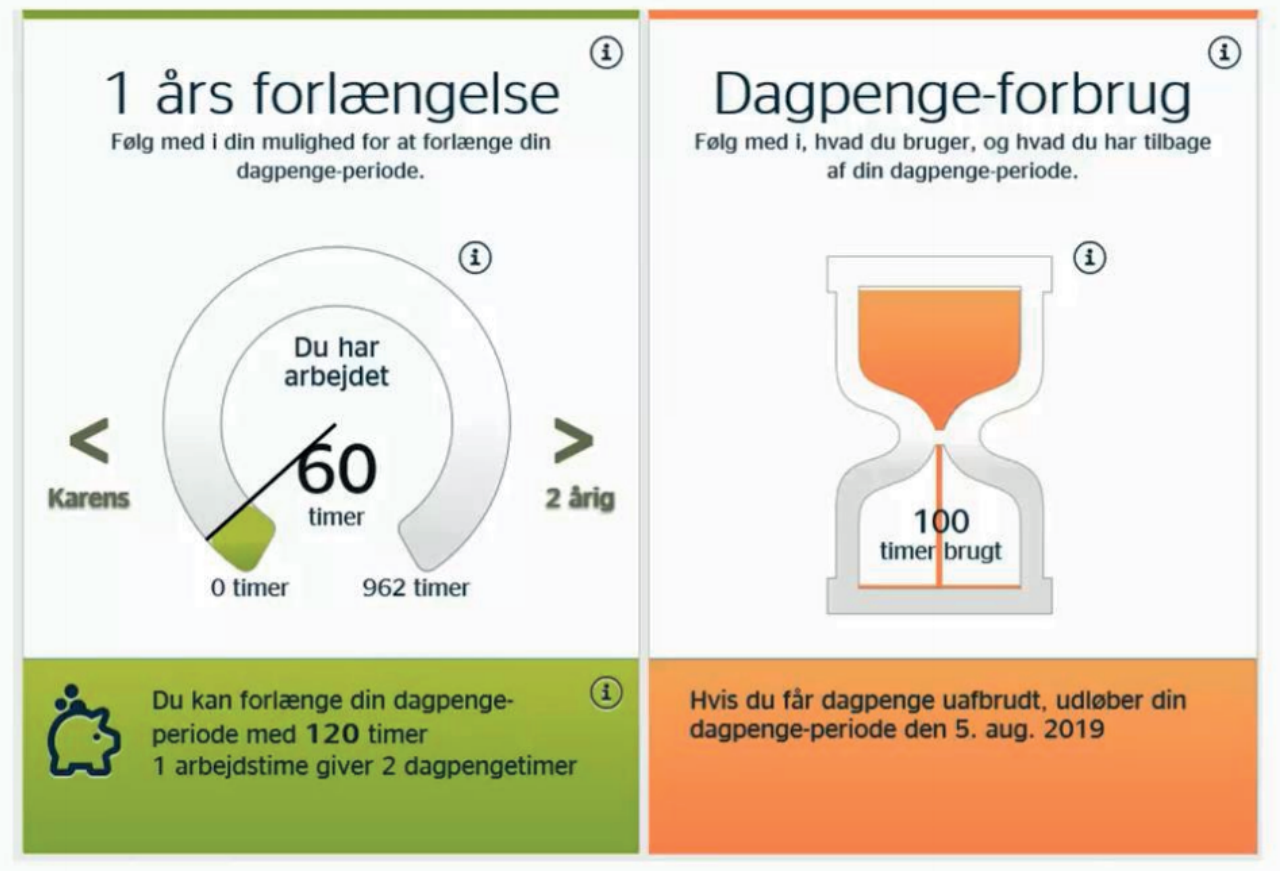

Dagpengekommissionen noterede, at den maksimale ydelsesperiode på to år i den daværende model ikke teoretisk kunne siges at tale til lediges nutidspræferencer (se Kvist, 2015 for en diskussion). Overlevelsesanalyser viste samtidigt, at ledige især forsvandt fra ledighed umiddelbart efter ledighedsstart og før ydelsesperiodens ophør, se Dagpengekommissionen (2015a). De mange midlertidige lappeløsninger og et kompliceret kontanthjælpssystem talte ikke til tabsaversionen. Hvordan kunne man aktivere tabsaversion og tale til nutidspræferencer tidligere? Svaret blev ved en ny brug af karensperioder.

Socialpolitisk er den principielt mest innovative del af reformen nok denne ny brug af karensperioder, det vil sige perioder uden ydelse. Traditionelt ligger karens i starten af en periode med dagpenge ved arbejdsløshed eller sygdom og har til formål at give forsikrede incitamenter til ikke at blive ledige eller syge. (Tilsvarende har arbejdsgiverne nogle gange ansvaret for at finansiere den første periode med ledighed (eller sygdom) for at undgå spekulation i kortvarig hjemsendelse af medarbejdere - arbejdsgivere skulle dengang som nu betale de to første dages ledighed, såkaldte G-dage.)

Antallet af karensdage i dagpengesystemet varierer over årene. Kommissionens observation var, at ledige ikke altid er selvforskyldte i deres afskedigelse. I 2015 var der ingen karensperiode ved uforskyldt ledighed (men der var som i dag karens på 111 timer (svarende til tre uger) ved selvforskyldt ledighed). Hvis man (gen)indførte karens i starten af periode ved uforskyldt ledighed, ville man operere med et incitament, som var rettet mod den ledige, der imidlertid ved arbejdsgivers afskedigelse sjældent kunne handle på incitamentet. Placering af karens i starten af ydelsesperioden gør, at ledige kan komme i den 
situation, at de efter en uønsket afskedigelse bliver straffet fra start i det sociale sikringssystem med en reduktion af ydelsen.

Spørgsmålet var, hvordan man aktivt kan bruge karensdage på en måde, der dels taler til dagpengemodtageres incitamenter, og dels er mulige for modtagerne at handle på? Columbus-ægget blev ideen om at indføre gentagne små karensperioder, som den enkelte kunne undgå ved selv mindre perioder af arbejde. "At piske med gulerødder" var tanken om, at de gentagne karensperioder ville opdele den ellers lange dagpengeperiode i mindre perioder, hvorved nutidspræferencer nemmere blev aktiveret. Tidligere studier har vist, at effekten af relativt små økonomiske tilskyndelser, dvs. karensperioder, kunne have ret store effekter, se Røed og Westlie (2012) samt Andersen, Svarer og Vejlin (2015). Dertil var tanken, at kommunikationen omkring karensperioderne italesættes som huller i ydelsesdækningen for at aktivere tabsaversion (i realiteten er der tale om mindre gennemsnitlige ydelsesreduktioner i de måneder karensperioder måtte forekomme). Således får ledige, når de tilgår deres joblog på jobnet.dk, præsenteret information om, hvor lang tid, der er til næste karensperiode og hvor mange timers beskæftigelse, der mangler for at "hoppe over" karensperioden, se figur 2.

Figur 2. Dagpengetællere oplyser, hvor meget arbejde der kræves for at undgå næste karensperiode

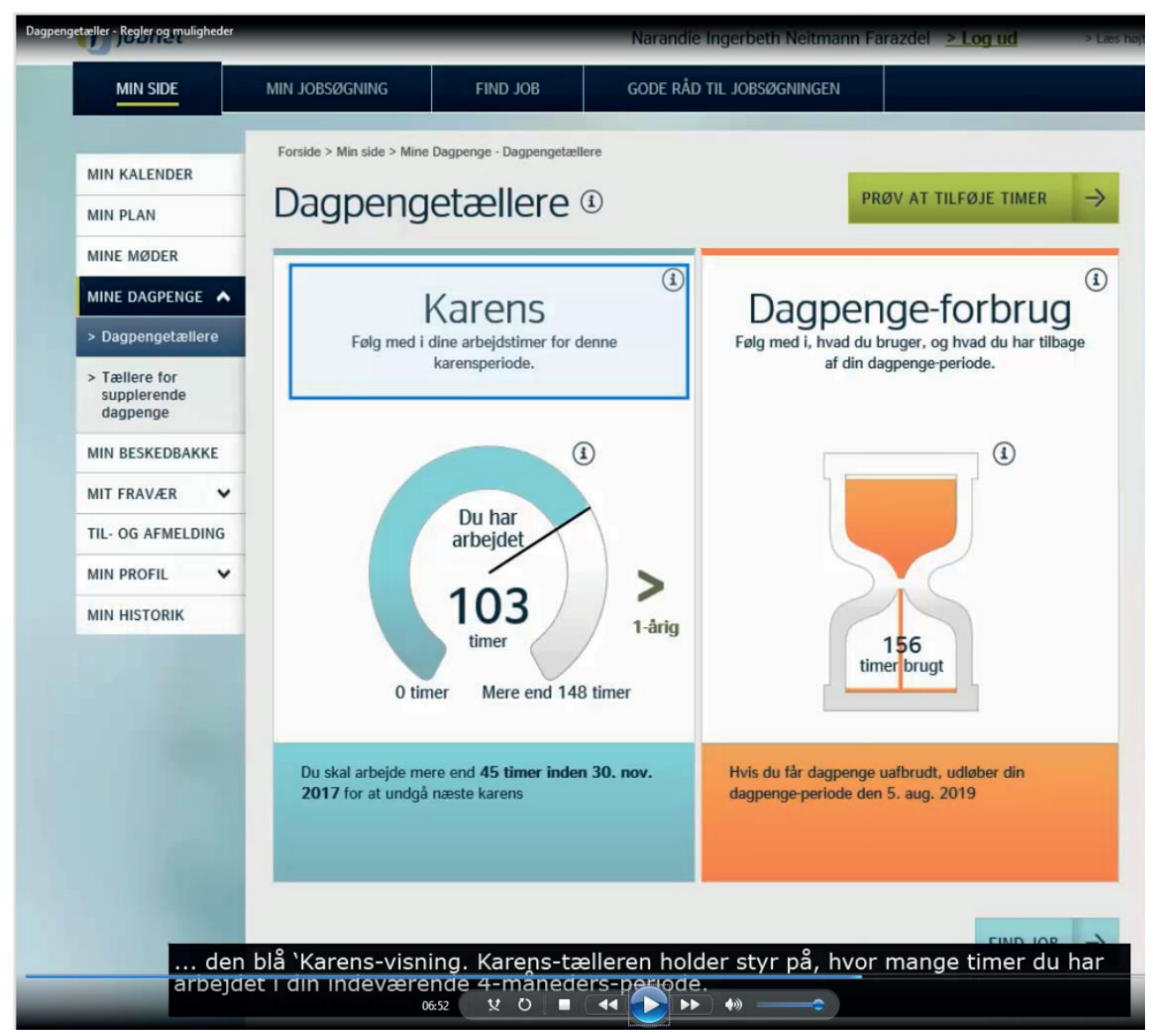


Samtidigt var karensdagene en både solidarisk og økonomisk givtig forretning for staten, da den foreslåede placering tre måneder efter starten af ydelsesperioden betød, at hovedparten af ledige bidrog til færre udgifter til dagpenge. (Partierne bag forliget om Dagpengereformen blev enige om en dags karens hver 4. måned mod forslagets to dage hver 3. måned og hentede en del af finansiering ved en dimittendsats på 71,5\% mod forslagets $78 \%$ ).

Dagpengekommissionens valg af korte karensperioder og beskæftigelseskontoen som alternativer til en mere klassisk økonomisk fokus på adfærdsregulering via ændringer (sænkning) af kompensationsgraden i sidste del af ledighedsperioden havde fordelingspolitiske konsekvenser. En trappemodel med en højere ydelse i starten af ledighedsperioden, som efter en periode nedsættes til et lavere niveau, vil især være til ugunst for de svagere ledige, som ender som langtidsledige. Hvis beskæftigelseskontoen og karensperioderne virker efter hensigten, reduceres langtidsledigheden, og færre risikerer at miste dagpengene, uden at dagpengene reduceres i sidste del af perioden for de svageste ledige. Derfor må Dagpengekommissionens løsning alt andet lige forventes at give anledning til mindre fordelingspolitisk ulighed end trappemodellen.

\section{Afsluttende betragtninger}

Det virker åbenbart, at Finansministeriet og andre relevante ministeriet bør interessere sig for adfærdsøkonomi eller, lidt bredere, behavioral public policy, det vil sige, hvordan man kan drage på adfærdsindsigter fra samfundsvidenskabelige empiriske studier i indretningen af offentlig politik og styring (se Bregn, 2019 for en nyere dansk indføring).

Med et sådant perspektiv opnås både en mere nuanceret diagnose af problemer og nye værktøjer til at løse disse problemer med. I casen om dagpenge betød anerkendelsen af begrænset rationalitet en forståelse af, at ledige - som andre mennesker - ikke altid kan gennemskue konsekvenser af komplekse valg. Anerkendelse af individers begrænsede handleevne betød for diagnosen, at selv når den ledige ved, hvad der er bedst for vedkommende, er det ikke altid muligt at handle på præferencerne.

På værktøjssiden betyder det, at ikke alene ydelsens størrelse og længde har betydning for individers valg og adfærd, men også det øvrige design af dagpengesystemer. Inddragelse af viden fra adfærdsøkonomiske og andre adfærdsorienterede studier giver viden, der kan bruges til at kvalificere reformer af offentlig politik (Chetty, 2015). Det ligger således i de adfærdsorienterede studiers DNA at bygge på empiriske undersøgelser, hvilket stemmer godt overens med trenden mod, at offentlig politik bør bygge på evalueringer og evidens.

I forhold til Dagpengekommissionens forslag fra 2015 ville det have været ønskeligt og vigtigt at have haft bedre muligheder for at vurdere de økonomiske og provenumæssige adfærdsøkonomiske effekter. Det ville formentlig have gjort "råderummet" for Dagpengereformen i 2015 større. Ikke desto mindre 
har tanker inspireret af adfærdsøkonomi været vigtige i indførsel af bl.a. den fleksible genoptjening med en beskæftigelseskonto og 1:2-princippet samt af gentagne karensperioder, der kan arbejdes væk. Fleksibel genoptjening og gentagne karensperioder har styrket incitamenter til at tage et arbejde i løbet af dagpengeperioden og øget den sociale tryghed - de to måske væsentligste mål med Dagpengereformen.

Hvorvidt adfærdsøkonomiske effekter direkte skal systematisk inddrages i modelapparatet, er et vanskeligere spørgsmål. Mulighederne for at få den tilstrækkelige og sikre empiriske evidens med ekstern validitet er måske stadig ikke altid til stede, fordi adfærdsøkonomisk forskning fortsat er i udviklingsfasen. Inddragelse kræver i mange tilfælde mere valid forskningsmæssig evidens om effekterne, som ikke er til stede i dag. Omvendt burde det - specielt for en så stor velfærdsstat som den danske - være højeste prioritet at få fremskaffet meget mere viden om, hvordan adfærdsøkonomiske effekter kan inddrages i designet af forskellige velfærdsordninger.

Modstandere af at inddrage adfærdsøkonomiske effekter vil sikkert argumentere med, at de øger usikkerheden ved modellerne. Modargumentet er, at der også er ganske betydelige usikkerheder om mange af de øvrige elasticiteter, der allerede nu indgår i modellerne. Ud fra et demokratisk synspunkt burde disse usikkerheder både ved de eksisterende modeller og fremtidige modeller, der potentielt kunne inddrage adfærdsøkonomiske effekter, håndteres ved at fremlægge sensitivitets- eller usikkerhedsanalyser. Det har imidlertid hidtil været almindeligt accepteret ikke at fremlægge usikkerhedsberegninger ved modellerne, så politikkerne "ikke frit kunne vælge" blandt resultaterne af modelkørsler. Det er måske netop denne holdning, dvs. ikke at fremlægge de usikkerheder, der helt indiskutabelt er ved de fleste modelberegninger, som er med til at føde ind til kritikken af Finansministeriets og andre økonomiske modeller for ikke at være politisk neutrale.

Mindre rationelle modeller med inddragelse af adfærdsøkonomiske effekter koblet med større transparens ved angivelser af sensitivitetsanalyser og usikkerheder kan være et vigtigt bidrag til at give regnemodellerne bedre kvalitet og ikke mindst legitimitet.

\section{Litteraturliste}

Andersen, Torben, Michael Svarer og Rune Vejlin (2015), Litterature review af effekter af indretning af arbejdsløshedsunderstøttelsessystemer, https://bm.dk/media/ 6096/revisedrapport20151004-pdf.pdf

Ariely, Dan (2008), Predictably Irrational, New York: Harper Collins.

Bregn, Kirsten (2019), Adfardsinformeret politik: Anvendelsen af indsigter fra adfordsøkonomi og psykologi $i$ offentlig politik, København: DJØF Forlag.

Babcock, Linda, William Kongdon, Lawrence Katz, og Sendhil Mullainathan (2012), Notes on behavioral eco- nomics and labour market policy, IZA Journal of Labour Policy, 1(2).

Chetty, Raj (2015), Behavioral Economics and Public Policy: A Pragmatic Perspective, American Economic Review, 105(5): 1-33.

Dagpengekommissionen (2015a), Dagpengemodellen, Teknisk Rapport, sidst tilgået d. 5. marts 2020 på https://bm.dk/media/6097/teknisk_analyserapportpdf.pdf, Dagpengekommissionens Sekretariat, Finansministeriet. 
Dagpengekommissionen (2015b), Dagpengekommissionens samlede anbefalinger, sidst tilgået d. 5. marts 2020 på https://bm.dk/media/6092/hovedrapport-pdf.pdf, København: Dagpengekommissionen.

Det Økonomiske Råd (2014), Dansk Økonomi, Efterår 2014.

Dohmen, Thomas (2014), Behavioral labor economics: Advances and future directions, Labour Economics, 30(2014): 71-85.

Frid-Nielsen, Snorre (2017), Jobsøgning med begrænset rationalitet. Adfærdsmæssige indsigter og tiltag, Politik \& Økonomi, 66-76.

Kahneman, Daniel (2011), Thinking, Fast and Slow, London: Macmillan.
Kvist, Jon (2015), Adfærdsøkonomi og arbejdsløshedsforsikring, Note til Dagpengekommissionen, sidst tilgået d. 5. marts 2020 på https://bm.dk/media/6093/note_ adfaerdsokonomi_kvist-pdf.pdf, København: Dagpengekommissionen.

Røed, Knut \& Lars Westlie (2012), Unemployment insurance in welfare states: The impacts of soft duration constraints, Journal of the European Economic Association, 10(3): 518-554.

Simon, Herbert (1982), Models of Bounded Rationality, Cambridge, MA: MIT Press.

Thaler, Richard H. \& Cass R. Sunstein (2008), Nudge: Improving decisions about health, wealth, and happiness, New Haven, CT: Yale University Press. 